\title{
New Diversity of Ralstonia solanacearum Strains Associated with Vegetable and Ornamental Crops in Florida
}

\author{
Pingsheng Ji, North Florida Research and Education Center, University of Florida, IFAS, Quincy 32351; Caitilyn \\ Allen, Amilcar Sanchez-Perez, and Jian Yao, Department of Plant Pathology, University of Wisconsin-Madison, \\ 53706; John G. Elphinstone, Plant Health Group, Central Science Laboratory, Sand Hutton, York, YO41 1LZ, UK; \\ Jeffrey B. Jones, Plant Pathology Department, University of Florida, IFAS, Gainesville 32611; and M. Timur Momol, \\ Plant Pathology Department, North Florida Research and Education Center, IFAS, University of Florida, Quincy
}

\begin{abstract}
Ji, P., Allen, C., Sanchez-Perez, A., Yao, J., Elphinstone, J. G., Jones, J. B., and Momol, M. T. 2007. New diversity of Ralstonia solanacearum strains associated with vegetable and ornamental crops in Florida. Plant Dis. 91:195-203.

In 2003 and 2004, 15 isolates of Ralstonia solanacearum were obtained from wilting plants of field-grown pepper (Capsicum апnиum) in south Florida and from pot-grown hydrangea (Hydrangea paniculata and H. macrophylla) and geranium (Pelargonium $\times$ hortorum) in commercial nurseries and retention ponds in north Florida. Diagnostic immunoassays and polymerase chain reaction (PCR) analyses identified all the isolates as $R$. solanacearum but not race 3 biovar 2. Pathogenicity studies on tomato, pepper, and tobacco revealed that all 15 strains had similar high virulence on tomato and all caused wilting of tobacco, although there were significant differences among the strains in aggressiveness on tobacco. An indigenous Florida tomato strain, race 1 biovar 1 (Rs5), caused no disease on tobacco and little or none on pepper. The three pepper strains were more aggressive than Rs5 or two hydrangea strains on all three pepper cultivars studied. Phylogenetic analysis based on an endoglucanase gene sequence indicated that these strains had three distinct origins. The three pepper strains belonged to phylotype I biovar 3 and clustered with strains from diverse hosts in Asia belonging to sequevar 13. The six geranium strains and four of the hydrangea strains were closely related to strains in sequevar 5, a distinct subcluster of phylotype II biovar 1 strains isolated from the French West Indies and Brazil. Two other biovar 1 strains from hydrangea and strains K60, AW, and Rs5 belonged to sequevar 7 in phylotype II and probably are native to North America. None of the Florida isolates belong to the highly regulated Select Agent race 3 biovar 2 subgroup, according to both the DNA sequence analysis and the biovar phenotypic test results. However, the race 3 biovar 2-specific B2 primers weakly amplified a product from some race 1 biovar 1 strains in real-time PCR, indicating that this assay may give false positives under some conditions. Given the high cost of a misdiagnosis, it seems advisable to use at least two independent diagnostic methods to confirm that a suspect isolate is $R$. solanacearum R3B2. This is the first report of the presence of $R$. solanacearum race 1 biovar 3 or phylotype I strains in North America, and the first report confirming $R$. solanacearum causing natural infection of hydrangea in Florida. Thus, $R$. solanacearum strains that are quite distinct from presumably indigenous strains are present and can infect diverse hosts in Florida.
\end{abstract}

Additional keywords: Lycopersicon esculentum, Nicotiana tabacum, solanaceous

Bacterial wilt caused by Ralstonia solanacearum is a serious disease and a major constraint in the production of many economically important crops, including tomato (Lycopersicon esculentum L.), potato (Solanum tuberosum L.), and tobacco (Nicotiana tabacum L.) in tropical, subtropical, and warm temperate regions of the world $(3,6,15,20)$. This bacterial pathogen occurs worldwide and has an extensive host range including hundreds of

Corresponding author: M. T. Momol

E-mail: tmomol@ufl.edu

Accepted for publication 13 September 2006

DOI: 10.1094/PDIS-91-2-0195

(C) 2007 The American Phytopathological Society plant species, which helps to make it one of the most important bacterial diseases of plants $(3,15)$. As a highly diversified pathogen, $R$. solanacearum is considered a species complex, a heterogeneous group of related strains $(9,12)$. There are hundreds of genetically distinct isolates of $R$. solanacearum. Historically, the species complex was subdivided into races based very loosely on host range, and into biovars based on ability to produce acid from a panel of carbohydrates $(5,14,15)$. A more phylogenetically meaningful classification scheme, based on sequence of several genes, divides the species complex into four phylotypes (33). This approach groups strains by geographic origin, such that strains from Asia are in phylotype I, those from the Americas are in phylotype II, those from Africa are in phylotype III, and others from Indonesia, which is the apparent center of diversity, are in phylotype IV (9). Phylotypes themselves can be subgrouped into sequevars, clusters of isolates with highly conserved DNA sequences; $R$. solanacearum sequevars sometimes share pathogenic traits or geographic origins.

In North America, bacterial wilt primarily occurs in the southeastern United States, causing significant losses on solanaceous crops such as tomato and potato. This disease is also extremely damaging on flue-cured tobacco, causing increasing losses in tobacco production in North and South Carolina, but not Florida $(10,22,42)$. In Florida, bacterial wilt occurs in fieldgrown tomato almost throughout the state but more commonly in north Florida. It also has caused considerable damage in potato and sunflower (Helianthus annuus L.) and occurred occasionally in tobacco and eggplant (S. melongea L.) in the field, and on imported geranium (Pelargonium $\times$ hortorum Bailey) and pothos (Epipremnum aureum (Lindl. \& Andre) Bunting) cuttings $(24,31,38)$. For the past three to four decades, bacterial wilt has not been as serious in pepper as in tomato or tobacco in the southeastern United States because prevalent strains are avirulent or less virulent on pepper than on tomato or tobacco $(22,24,30,47)$. There is some phenotypic and genetic variations among $R$. solanacearum strains from Florida $(29,47)$ or the southeastern United States $(22,28,42,43)$; however, to date, all the strains were identified as race 1 biovar 1 .

In 2002, the subgroup of $R$. solanacearum known as race 3 biovar 2 (R3B2) was listed in the United States as a bioterrorism Select Agent (25). Although R3B2 is best known as a pathogen of potato, these strains also can infect tomato and geranium plants, and the pathogen occasionally has been introduced into North America and Europe on geranium cuttings produced in Africa or Central America $(19,23,46,49)$. Biologically, R3B2 strains can be identified by the biovar test and by host range because, unlike many race 1 strains, they neither cause disease nor induce a hypersensitive response (HR) on tobacco. Two published polymerase chain reaction (PCR) primer sets specifically identify R3B2 strains; both primers are derived 
from an apparent prophage remnant present in the genomes of all tested R3B2 strains $(8,11,48)$. Although they are widely distributed in Asia, Africa, and South and Central America, and are found in some soils and waterways in Europe $(6,7,18)$, R3B2 strains are not known to be established in North America. Hence, there are no records indicating the presence on the U.S. mainland of any $R$. solanacearum races or biovars other than race 1 biovar 1 , which is considered endemic (20). Other types, such as race 4 biovar 4 and race 2 biovar 1, are present in Hawaii $(1,51)$.

In 2003 and 2004, R. solanacearum was isolated from wilting plants of field-grown pepper (Capsicum annuum L.) in south Florida and pot-grown hydrangea ( $\mathrm{Hy}$ drangea paniculata Sieb. and H. macrophylla (Thunb.) Ser.) in a commercial nursery in north Florida. In $2004, R$. solanacearum isolates were collected from wilting geranium (Pelargonium $\times$ hortorum Bailey) plants and pond water at a commercial ornamental production facility in north Florida. Fields with a long cropping history of the solanaceous $R$. solanacearum hosts tomato and tobacco were located nearby and were connected to the pond via a network of irrigation ditches. At times, pond water was used to irrigate ornamental plants. This facility experienced an outbreak of Southern wilt of geranium in 2002, and studies indicated that the responsible strains belonged to race 1 biovar 1 (38). Both race 1 and R3B2 strains can infect and wilt geranium plants. Because Federal law now mandates strict new reporting, security, and quarantine responses to any find of R3B2, accurate diagnosis of this pathogen is critically important.

This study was conducted to determine the cause of the various occurrences of wilting on pepper, hydrangea, and geranium plants in Florida based on immunoassay, PCR, host range tests, HR on tobacco, biovar tests, and phylotype and sequevar analyses of the pathogens. We found surprising diversity among the $R$. solanacearum strains isolated from these host plants, which were not limited to known indigenous strains. We also report here that $R$. solanacearum race 1 biovar 3 , which was not known to exist in North America, is present in Florida.

\section{MATERIALS AND METHODS}

Strains and culture conditions. The $R$. solanacearum strains used in this research are described in Table 1. Strains Rs121, Rs122, and Rs123 were isolated in 2003 from wilted pepper plants $(C$. annuum) in a field in Hillsborough County, FL. Strains Rs116 to Rs120 and Rs124 were isolated from wilted pot-grown hydrangeas $(H$. paniculata and $H$. macrophylla) in 2003 and 2004 in Gadsden County, FL. Strains Rs125 to Rs130 were isolated in a serious disease outbreak in 2004 from wilted pot- grown geranium (Pelargonium $\times$ hortorum) or pond water used to irrigate the geranium plants in Gadsden County, FL. Bacterial strains from all plants were isolated from basal stems of infected seedlings, after surface sterilization of the stem tissue with $70 \%$ ethanol, and cultured on a previously modified semiselective SMSA medium (36). $R$. solanacearum strain Rs5 (37), isolated from wilted tomato plants in Quincy, FL, was included in the study. Diverse representative $R$. solanacearum strains were used as comparative controls. These strains represent different biovars, races, and phylotypes. Bacterial strains routinely were cultured in casamino acid peptone glucose (CPG) broth (16) or on CPG plus triphenyltetrazolium chloride (TZC) agar medium (21) at $28^{\circ} \mathrm{C}$. Bacterial cultures were stored in sterile water at room temperature.

Immunoassay strip test. Bacterial isolates were tested with $R$. solanacearumspecific immunoassay strips according to the manufacturer's instructions (Agdia, Inc., Elkhart, IN). Tomato strain Rs5 was used as a positive control; duplicate cultures of each strain were tested with the strips.

PCR analyses. Total chromosomal DNA for PCR templates was isolated from $R$. solanacearum cells by standard methods (2). All PCR reactions were performed in $250-\mu$ tubes using a Techne Techgene thermocycler (Techne Ltd., Cambridge,

Table 1. Ralstonia solanacearum strains used in this research ${ }^{\mathrm{a}}$

\begin{tabular}{|c|c|c|c|c|c|c|c|c|c|}
\hline Strain $^{b}$ & Race & Biovar & Phylotype & Sequevar & $\begin{array}{l}\text { Ct value in } \\
\text { real-time PCR }\end{array}$ & $\begin{array}{c}\text { HR on tobacco } \\
\text { (at } 23 \mathrm{~h})\end{array}$ & Host & Origin & Year isolated \\
\hline Rs5 & 1 & 1 & II & 7 & ND & Positive & Tomato & Quincy, FL & 2000 \\
\hline Rs37 & 1 & 1 & II & 5 & ND & Partial HR & Geranium & Quincy, FL & 2001 \\
\hline Rs116 & 1 & 1 & II & 7 & ND & Positive & Hydrangea & This study & 2003 \\
\hline Rs117 & 1 & 1 & II & 7 & ND & ND & Hydrangea & This study & 2003 \\
\hline Rs118 & 1 & 1 & II & 5 & ND & ND & Hydrangea & This study & 2004 \\
\hline Rs119 & 1 & 1 & II & 5 & ND & ND & Hydrangea & This study & 2004 \\
\hline Rs 120 & 1 & 1 & II & 5 & ND & ND & Hydrangea & This study & 2004 \\
\hline Rs121 & 1 & 3 & I & 13 & ND & Negative & Pepper & This study & 2003 \\
\hline Rs 122 & 1 & 3 & I & 13 & ND & ND & Pepper & This study & 2003 \\
\hline Rs123 & 1 & 3 & I & 13 & ND & ND & Pepper & This study & 2003 \\
\hline Rs124 & 1 & 1 & II & 5 & ND & ND & Hydrangea & This study & 2004 \\
\hline Rs 125 & 1 & 1 & II & 5 & 34.15 & ND & Geranium & This study & 2004 \\
\hline Rs126 & 1 & 1 & II & 5 & 34.38 & ND & Geranium & This study & 2004 \\
\hline Rs127 & 1 & 1 & II & 5 & 34.64 & ND & Geranium & This study & 2004 \\
\hline Rs 128 & 1 & 1 & II & 5 & 32.24 & ND & Geranium & This study & 2004 \\
\hline Rs 129 & 1 & 1 & II & 5 & 39.28 & ND & Pond water & This study & 2004 \\
\hline Rs 130 & 1 & 1 & II & 5 & 36.06 & ND & Pond water & This study & 2004 \\
\hline UW27 & 1 & 1 & II & ND & 40.00 & ND & Tobacco & Quincy, FL & 1955 \\
\hline UW30 & 1 & 1 & II & ND & ND & ND & Tomato & Trinidad & 1957 \\
\hline UW90 & 1 & 1 & II & ND & 40.00 & ND & Tobacco & Brazil & 1968 \\
\hline UW154 & 1 & 1 & II & ND & 35.26 & ND & Tobacco & Colombia & 1966 \\
\hline UW256 & 1 & 1 & II & ND & 40.00 & ND & Potato & Costa Rica & 1972 \\
\hline UW278 & 1 & 1 & II & ND & 40.00 & ND & Tobacco & Mexico & 1977 \\
\hline UW551 & 3 & 2 & II & 1 & 19.22 & Negative & Geranium & Kenya & 2003 \\
\hline K60 & 1 & 1 & II & 7 & 40.00 & Negative & Tomato & Raleigh, NC & 1954 \\
\hline CIP 430 & 3 & 2 & II & 1 & 19.48 & ND & Potato & Peru & 1991 \\
\hline CFBP3858 & 3 & 2 & II & 1 & 21.93 & ND & Potato & Netherlands & 1996 \\
\hline
\end{tabular}

a Phylotype, sequevar, race, and biovar data for the strains other than those characterized in this study are from the literature. $\mathrm{Ct}=\mathrm{critical}$ threshold, $\mathrm{PCR}=$ polymerase chain reaction, $\mathrm{HR}=$ hypersensitive response, and $\mathrm{ND}=$ not determined.

b Characteristics of strains used in phylogenetic analysis are given in Figure 2. Alternative names for strains Rs125, Rs126, Rs127, Rs128, Rs129, Rs130, K60, and CFBP3858 are RS04-46A, RS04-46D, RS04-47B, RS04-47D, RS04-56bac7, RS04-56bac8, CFBP2047, and JS907, respectively.

c PCR cycle at which real-time amplification was first detected. The B2 primers (Weller et al. 2000) were used in the PCR analysis. Ct values <25 are rapid positives, those in the 30-to-39 range are slow positive, and those with a 40 are negative. 
UK). For most PCR reactions, the reaction mixture ( $25 \mu$, total volume) contained 30 ng of template genomic DNA, 1× PCR buffer without magnesium, $2.5 \mathrm{mM} \mathrm{Mg}{ }^{++}$, $0.25 \mathrm{mM}$ each dNTP, $20 \mathrm{pmol}$ of each primer, and $5 \mathrm{U}$ of $\mathrm{Taq}$ polymerase. DNA was amplified using a 3-min hot start at $96^{\circ} \mathrm{C}$, followed by 30 cycles of $15 \mathrm{~s}$ at $94^{\circ} \mathrm{C}, 58 \mathrm{~s}$ at $30^{\circ} \mathrm{C}$, and $30 \mathrm{~s}$ at $72^{\circ} \mathrm{C}$. Reactions were completed with $5 \mathrm{~min}$ at $72^{\circ} \mathrm{C}$. The slightly different endoglucanase $(e g l)$ gene PCR conditions are described below. All PCR products were electrophoresed through a $1.5 \%$ agarose gel and visualized with UV light after ethidium bromide staining.

Classification of all $R$. solanacearum strains to species was confirmed by PCR using the $R$. solanacearum universal primer pair 759/760, which amplifies a 280-bp fragment from all $R$. solanacearum strains (32). Strains were classified into phylotypes by means of the phylotypespecific multiplex PCR reaction, which classified all $R$. solanacearum strains into one of the four phylotypes (9). Race 3 strains were identified using the race 3specific PCR primer pair 630/631 (8). Some suspect race 3 strains also were analyzed using the real-time PCR assays of Weller et al. (48) with RS (amplifies all $R$. solanacearum strains) and B2 (amplifies only R3B2 strains) primer/probe sets. A critical threshold $(\mathrm{Ct})$ PCR cycle at which real-time amplification was first detected was used to determine whether a bacterial strain was $\mathrm{R} 3 \mathrm{~B} 2$. $\mathrm{Ct}$ values $<25$ were rapid positives, those in the 30-to-39 range were slow positive, and those with a 40 were negative. Some of the PCR primer sequences are listed in Table 2.

Endoglucanase gene cloning, sequencing, and analysis. A 750-bp fragment of the $R$. solanacearum egl gene was amplified as described by Poussier et al. $(33,34)$ using the Endo-F/Endo-R primer pair (Table 2). Reactions contained $1 \times P f u$ polymerase buffer, $0.25 \mathrm{mM}$ each dNTP, $6 \%$ dimethyl sulfoxide, 100 pmol of each primer; $100 \mathrm{ng}$ of template DNA, and 2.5 U of Pfu Ultra High Fidelity Polymerase (Stratagene, Inc., La Jolla, CA) in a final volume of $50 \mu \mathrm{l}$. The egl sequence was amplified using a 3 -min hot start at $96^{\circ} \mathrm{C}$ followed by 30 cycles of $30 \mathrm{~s}$ at $95^{\circ} \mathrm{C}, 45 \mathrm{~s}$ at $69^{\circ} \mathrm{C}$, and $2 \mathrm{~min}$ at $72^{\circ} \mathrm{C}$, with a final $10-$ min extension step at $72^{\circ} \mathrm{C}$.

The amplified $e g l$ gene fragments were ligated into the $\mathrm{pCR}$ Blunt II-TOPO vector (Invitrogen, Inc., Carlsbad, CA) according to the manufacturer's instructions. The ligation mixture was electroporated into competent Escherichia coli DH5 $\alpha$ cells, plated onto Luria Bertani medium plus kanamycin at $25 \mu \mathrm{g} / \mathrm{ml}$, and incubated overnight at $37^{\circ} \mathrm{C}$. White colonies, representing potential transformed cells, were screened by PCR using the Endo-F/Endo$\mathrm{R}$ primer pair and the standard Taq polymerase reaction conditions described above. Plasmid DNA from colonies yielding a 750-bp amplicon were isolated using a standard protocol (2). The cloned DNA inserts were sequenced in both directions at the University of Wisconsin Biotechnology Center. Sequences were analyzed using the Jellyfish 3.0 software package (LabVelocity, Burlingame, CA). A rooted phylogenetic tree was constructed using the ARB program in Biology Workbench, combining the sequences reported here with diverse $R$. solanacearum egl sequences previously deposited in the GenBank database.

Biovar characterization. Strains were classified to biovar using a variation of the physiological tests developed by Hayward $(5,14)$, which assay the ability of strains to oxidize a panel of sugars and sugar alcohols. Briefly, $2 \mathrm{ml}$ of Hayward's medium containing $1 \% \quad(\mathrm{wt} / \mathrm{vol})$ filter-sterilized dextrose, lactose, dulcitol, or D-mannitol were dispensed into wells of 24-well tissue culture plates; Hayward's medium without a carbon source served as a control. A cell suspension of $1 \times 10^{8} \mathrm{CFU} / \mathrm{ml}$ was prepared from overnight CPG broth cultures of each test strain. All tests included control strains of biovar 1 (K60), biovar 2 (UW551), biovar 3 (GMI1000), biovar 4 (UW151), and biovar 5 (UW373). Each well was inoculated with $3 \mu \mathrm{l}$ of the prepared suspension and each test was replicated three times, including noninoculated controls. The plates were incubated at $28^{\circ} \mathrm{C}$ for 3 weeks and color change in each well was recorded daily.

HR on tobacco. We infiltrated tobacco leaves with one representative strain from each Florida sequevar group in order to determine the response of tobacco, which sometimes is used as a diagnostic differential host. Fully expanded leaves of tobacco (cv. Bottom Special) were syringe infiltrated with a suspension of $R$. solanacearum cells adjusted to $1 \times 10^{7} \mathrm{CFU} / \mathrm{ml}$ in sterile distilled water; distilled water and $R$. solanacearum strain GMI1000 served as negative and positive controls, respectively. Plants were maintained at $28^{\circ} \mathrm{C}$ with a 12-h day length. Infiltrated areas were rated for tissue collapse, drying, and browning at $23 \mathrm{~h}$ post inoculation.

Pathogenicity study. The virulence of 16 strains, 3 from pepper, 6 from hydrangea, 6 from geranium, and 1 from tomato, were evaluated on susceptible tomato (cv. Solar Set) and tobacco (N. tabacum cv. NC55). Tomato and tobacco seedlings were grown from seed in Terra-lite agricultural mix (Scott Sierra Horticultural Products Co., Marysville, $\mathrm{OH}$ ) in expanded polystyrene flats with $3.5-$ by-3.5-cm cells. Bacterial cultures were grown on $\mathrm{CPG}$ agar plates at $28^{\circ} \mathrm{C}$ for $48 \mathrm{~h}$, washed from the plates, and adjusted to approximately 1 $\times 10^{8} \mathrm{CFU} / \mathrm{ml}$ using sterile deionized water. Unwounded 6-week-old tomato or 7week-old tobacco plants were inoculated by pouring $5 \mathrm{ml}$ of $R$. solanacearum suspension into each transplant cell, with five tomato or five tobacco plants for each strain. Seedlings were transplanted into 10$\mathrm{cm}$ pots containing the potting mix 3 days after inoculation. Pots were placed in a saucer containing water to maintain high soil moisture in order to facilitate infection and wilt development. The plants were supplied with Peter's Peat Lite Special $(15: 16: 17, \mathrm{~N}-\mathrm{P}-\mathrm{K})$ at 10 -day intervals at a rate of $7.5 \mathrm{~g} /$ liter of water. Plants were maintained in a greenhouse with temperatures of 23 to $28^{\circ} \mathrm{C}$ during the night and 30 to $35^{\circ} \mathrm{C}$ during the day. The pots were arranged in randomized complete blocks with five replicates and the experiment was

Table 2. Primers used for strain characterization

\begin{tabular}{|c|c|c|c|}
\hline Name & Concentration (pmol) & Primer sequence & Reference $^{\mathrm{a}}$ \\
\hline \multicolumn{4}{|l|}{ Multiplex } \\
\hline Nmult:21:1F & 7 & 5'-CGTTGATGAGGCGCGCAATTT-3' & 9 \\
\hline Nmult:21:2F & 7 & 5'-AAGTTATGGACGGTGGAAGTC-3' & 9 \\
\hline Nmult:23:AF & 18 & 5'-ATTACSAGAGCAATCGAAAGATT-3' & 9 \\
\hline Nmult:22:InF & 7 & 5'-ATTGCCAAGACGAGAGAAGTA-3' & 9 \\
\hline Nmult:22:RR & 10 & 5'-TCGCTTGACCCTATAACGAGTA-3' & 9 \\
\hline 759-universal & 6 & 5'-GTCGCCGTCAACTCACTTTCC-3' & 32 \\
\hline 760-universal & 6 & 5' -GTCGCCGTCAGCAATGCGGAATCG-3' & 32 \\
\hline \multicolumn{4}{|l|}{ Endoglucanase } \\
\hline Endo-F & 100 & 5'-ATGCATGCCGCTGGTCGCCGC-3' & This study \\
\hline Endo-R & 100 & 5'-GCGTTGCCCGGCACGAACACC-3' & This study \\
\hline \multicolumn{4}{|l|}{ Race 3} \\
\hline 630 & 20 & 5'-ATACAGAATTCGACCGGCACG-3' & 8 \\
\hline 631 & 20 & 5'-AATCACATGCAATTCGCCTACG-3' & 8 \\
\hline
\end{tabular}

a 9 = Fegan and Prior 2005; 32 = Opina et al. 1997; and 8 = Fegan et al. 1998. 
repeated twice. Wilting was assessed weekly after inoculation for a total of 4 weeks and disease incidence on tomato was quantified as percentage of plants wilted. Disease severity on tobacco was evaluated using the following index modified from Winstead and Kelman (50): $0=$ no symptoms, $1=$ one leaf with symptoms, $2=$ two or three leaves wilted, $3=$ all except the top two or three leaves wilted, $4=$ whole plant wilted. Analysis of variance (ANOVA) was used to analyze wilt index data at each assessment date using the Statistical Analysis System (SAS; SAS Institute, Cary, NC). Orthogonal contrasts and least significant difference were used to compare the means.

Six $R$. solanacearum strains, including Rs121, Rs122, and Rs123 isolated from pepper, Rs116 and Rs117 from hydrangea, and Rs5 from tomato, were tested for pathogenicity on different cultivars of pepper. Pepper seedlings of three susceptible cultivars (Aruba, Cindy Lee, and X3R Camelot) were grown from seed in Terralite agricultural mix in expanded polystyrene flats. Unwounded 5-week-old plants were inoculated by applying $5 \mathrm{ml}$ of $R$. solanacearum suspension into each transplant cell, using five plants of each cultivar for each strain. Preparation of the inoculum, transplanting, fertilization, and disease assessment were as described above on tomato. The experiment was repeated twice under greenhouse conditions. At the end of the experiments, wilted plants were sampled for bacterial ooze and isolation of $R$. solanacearum on modified SMSA medium. Ooze was obtained by placing a cut stem from the lower part of the main stem into sterile water. Presumptive colonies of $R$. solanacearum were confirmed by $R$. solanacearum-specific immunostrip tests as described above.

Selected $R$. solanacearum strains (four from hydrangea and two from geranium) were tested for pathogenicity on hydrangea and geranium, respectively. Hydrangea plants (H. paniculata cv. Limelight) were grown from rooted cuttings for 5 weeks in 6.5-by-6.5-by-9-cm cells containing potting mix (Imperial Nurseries, Quincy, FL). Geranium seedlings (Pelargonium $\times$ hortorum cv. Glamour Scarlet) were grown from seed in 10-cm pots (Young's Plant Farm,
Auburn, AL). Five geranium plants, about $15 \mathrm{~cm}$ in height, were inoculated with each of the selected strains by pouring $30 \mathrm{ml}$ of bacterial suspension $\left(1 \times 10^{8} \mathrm{CFU} / \mathrm{ml}\right)$ into each pot. Six hydrangea plants were inoculated with each strain by pouring into each cell $10 \mathrm{ml}$ of bacterial suspension, three plants with $1 \times 10^{8} \mathrm{CFU} / \mathrm{ml}$ and three with $3 \times 10^{7} \mathrm{CFU} / \mathrm{ml}$. Noninoculated hydrangea and geranium plants were used as controls. Plants were transplanted into Terra-lite agricultural mix in 16-cm pots 3 days after inoculation. The plants were maintained in the greenhouse as described earlier. Plants were rated for wilting twice weekly until 5 weeks after transplanting. At the end of the experiments, symptomatic plants were examined for bacterial ooze, and $R$. solanacearum was reisolated and confirmed as described above.

\section{RESULTS}

Immunoassay and PCR identification of $\boldsymbol{R}$. solanacearum strains. All 15 strains isolated on SMSA from pepper, hydrangea, geranium, and associated pond water in Florida were confirmed to be $R$. solanacearum by the immunoassay strip test. Further, PCR using the $R$. solanacearum universal primer pair 759/760 amplified the expected single 280-bp fragment from all the strains (data not shown). However, none of the 15 strains contained DNA that was amplified by the race 3-specific primer set 630/631, which indicated that none of these Florida isolates belonged to the quarantined subgroup R3B2.

A quantitative real-time PCR assay (48) using the universal RS primer/probe set amplified the expected $R$. solanacearum target DNA sequence from the strains tested (data not shown). Real-time PCR using the biovar 2-specific B2 primer/ probe assay also amplified the expected target sequence from the biovar 2 reference strains UW551 and CBFP3858 as well as from biovar 1 strain CIP430 (a 1991 potato isolate from Peru). However, this target sequence also was slowly amplified from the Florida geranium isolates (Rs125 to Rs130) as well as from reference isolate UW154 (a biovar 1 tobacco isolate from Colombia). Slow amplification appeared as a delayed (higher) $\mathrm{Ct}$ cycle at which amplification was first detected by the fluo-

Table 3. Pathogenicity of Ralstonia solanacearum strains on different cultivars of pepper under greenhouse conditions

\begin{tabular}{lcccc}
\hline & & \multicolumn{2}{c}{ Disease severity on cultivars of pepper } \\
\cline { 3 - 5 } Strain & Original host & X3R Camelot & Cindy Lee & Aruba \\
\hline Rs5 & Tomato & $0(0)$ & $0(0)$ & M $(50)$ \\
Rs116 & Hydrangea & $0(0)$ & $\mathrm{L}(30)$ & $\mathrm{M}(60)$ \\
Rs117 & Hydrangea & $0(0)$ & $\mathrm{L}(40)$ & $\mathrm{M}(60)$ \\
Rs121 & Pepper & $\mathrm{H}(100)$ & $\mathrm{H}(100)$ & $\mathrm{H}(100)$ \\
Rs122 & Pepper & $\mathrm{H}(100)$ & $\mathrm{H}(100)$ & $\mathrm{H}(100)$ \\
Rs123 & Pepper & $\mathrm{H}(100)$ & $\mathrm{H}(100)$ & $\mathrm{H}(100)$ \\
\hline
\end{tabular}

${ }^{a}$ Disease severity was based on the final assessment made 28 days after inoculation. $\mathrm{H}$ (high) $=76$ to $100 \%$ plants wilted, $\mathrm{M}$ (medium) $=41$ to $75 \%$ plants wilted, $\mathrm{L}$ (low) $=1$ to $40 \%$ plants wilted, and 0 $=$ no plants with symptom. Values in parentheses are percentage of plants wilted. rescent reporter (Table 1) in comparison with the $\mathrm{Ct}$ value obtained with the RS assay on the same template DNA (data not shown). No amplification of DNA was observed with the B2 assay from DNA of any of the other biovar 1 reference strains tested.

Pathogenicity study. Hydrangea plants inoculated with strains Rs116 to Rs119 started to wilt 7 to 8 days after inoculation. All inoculated plants, except one inoculated with Rs116, developed symptoms within 5 weeks after inoculation. The plants either were completely wilted or had some branches wilted. Geranium plants inoculated with Rs125 and Rs127 developed wilt symptoms 5 days after inoculation and, 2 weeks after inoculation, all inoculated geraniums were wilted, with lower leaves chlorotic and plants largely dead. The cause of wilt on the hydrangea and geranium plants was confirmed to be $R$. solanacearum by reisolation of the bacterium from wilted plants followed by positive immunoassay strip test of the bacterial cultures obtained. Noninoculated control plants did not wilt.

The three strains isolated from pepper were highly virulent on all three pepper cultivars tested (Table 3). Cv. Aruba was the most susceptible, developing symptoms within a week, and all inoculated plants were wilted and dead 3 weeks after inoculation. Cvs. Cindy Lee and X3R Camelot began to wilt 9 to 10 days after inoculation, and all plants inoculated with the three pepper strains were dead 4 weeks after inoculation. Strains Rs116 and Rs117, isolated from hydrangea, were moderately virulent on Aruba and relatively weakly virulent on Cindy Lee (Table 3). Plants started to wilt 10 days after inoculation and, after 4 weeks, $40 \%$ of Cindy Lee and $60 \%$ of Aruba plants were dead. Neither Rs116 nor Rs117 caused disease on X3R Camelot. Similarly, none of the X3R Camelot or Cindy Lee seedlings developed symptoms following inoculation with the tomato strain Rs5, although Rs5 was moderately virulent on Aruba. The cause of wilt on the pepper plants was confirmed to be $R$. solanacearum by reisolation of the bacterium and testing with immunoassay strips as described previously.

The 15 new Florida strains and Rs5 were all highly virulent on the susceptible tomato cv. Solar Set. Inoculated plants started to wilt 5 to 7 days after inoculation, and all inoculated plants were dead in 3 weeks (data not shown). In contrast to their aggressiveness on tomato, the strains varied significantly in virulence on NC55 tobacco. Tomato strain Rs5 did not cause any symptoms on tobacco in repeated assays. The three strains from pepper appeared most virulent on tobacco, with all inoculated plants dead within 4 weeks after inoculation. Based on the final disease index, the pepper strains were significantly 
more aggressive on tobacco than most of the strains from geranium, hydrangea, or tomato, except for Rs118, Rs119, and Rs120, which were isolated from hydrangea (Fig. 1). The six geranium strains rarely caused complete wilt or death of the whole tobacco plant under our experimental conditions. Disease severity on tobacco inoculated with these geranium strains was significantly lower than that of the three pepper strains and three of the hydrangea strains (Rs118, Rs119, and Rs120) at 3 and 4 weeks after inoculation (Fig. 1). There were some differences in disease severity among the geranium strains, but the differences were not statistically significant. Among the hydrangea strains, Rs118, Rs119, and Rs120 appeared more aggressive on tobacco than Rs116 and Rs117; however, there was a significant difference in disease severity between Rs119 or Rs120 and Rs117 only 3 weeks after inoculation (Fig. 1).

Biovar characterization. We determined the biovar classification of the 15 strains isolated from pepper, hydrangea, and geranium according to their ability to utilize dextrose, mannitol, and dulcitol and to oxidize lactose. Strains Rs121, Rs122, and Rs123, all isolated from pepper, belonged to biovar 3 . All the other new Florida strains belonged to biovar 1 (Table 1).

Phylogenetic analysis. A 750-bp internal fragment of the $e g l$ gene, which encodes a moderately conserved $R$. solanacearum pathogenicity factor, was cloned and sequenced in order to more precisely place the various isolates within the species complex. Integration of the egl sequences from the Florida isolates into the existing $R$. solanacearum phylogenetic database $(9,33,34)$ revealed that these strains fell into three distinct groups (Fig. 2).

Multiplex PCR analyses indicated that the three pepper strains belong to phylotype I, a group believed to have originated in Asia (Table 1). Pepper isolates Rs 121 and Rs123 shared an identical egl sequence, which clustered with strains isolated from diverse hosts in Asia that belong to sequevar 13 (Fig. 2). The $e g l$ sequences from the Florida pepper isolates were identical to those from strain QL14, isolated from ginger in the Philippines, and Taiwanese tomato strains PSS244, PSS245, and PSS248; it differs by a single nucleotide from JT523, isolated from potato on Reunion Island. The pepper strains also are related to sequevar 12 strain GMI1000, which has been completely sequenced (44). This result is consistent with the pepper strains' classification in phylotype I and biovar 3 .

Phylogenetic sequevar analysis demonstrated that strains Rs116 and Rs117, isolated from wilting hydrangea plants, belong to sequevar 7, which includes tomatoinfecting strains from the southeastern United States such as K60 and AW. The
Florida tomato strain Rs5 and strain UW27, isolated from tobacco in Gadsden County, FL in 1955, also fell into this group. In contrast, strains Rs118, Rs119, Rs120, and Rs124, which also were isolated from wilting hydrangea plants, were phylogenetically quite distinct. They grouped with strains in sequevar 5, a distinct subcluster of phylotype II race 1 biovar 1 strains isolated from solanaceous hosts in the French West Indies and coastal Brazil (Fig. 2).

Molecular and phenotypic analysis of $R$. solanacearum strains Rs125 to Rs130 collected from wilting geranium plants and nearby pond water in the 2004 outbreak indicated that these strains were indistinguishable from race 1 biovar 1 strain Rs37, which was isolated from the Florida outbreak of southern wilt of geranium in 2002. The $e g l$ gene sequences from strains Rs125 to Rs130 were identical, indicating that the isolates were probably clonal. Phylogenetic analysis of these sequences placed isolates Rs125 to Rs130 and Rs37 in sequevar 5, along with hydrangea strains Rs118, -119, -120, and -124 as mentioned above (Table 1). The closest relative to the Florida geranium strains was Rs120 and E81, which were isolated from hydrangea in Florida and tomato on the Caribbean island of Guadeloupe, respectively. The Florida geranium strains were quite distinct from presumably indigenous $R$. solanacearum strains isolated from the southeastern United States, such as K60, Rs5, Rs116, and Rs117. None of the egl sequence fragments analyzed from any Florida isolate was closely related to those in the R3B2 cluster, which appears essen-

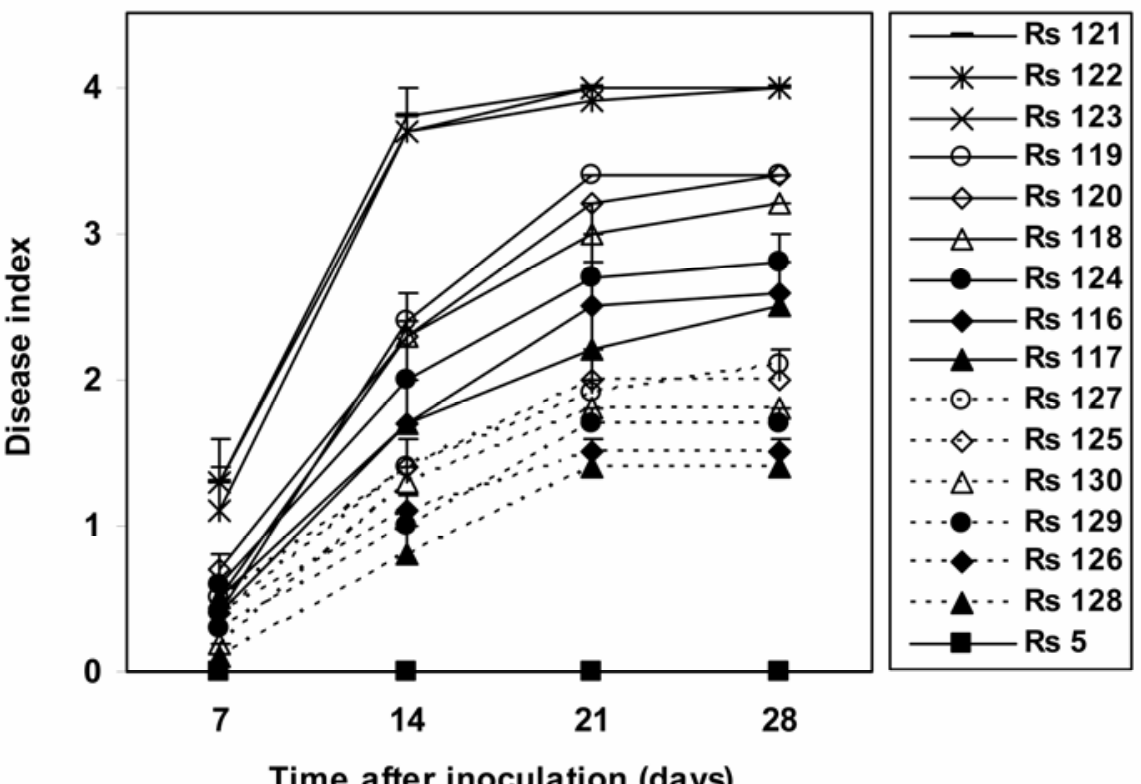

Fig. 1. Severity of bacterial wilt on tobacco after inoculation with different strains of Ralstonia solanacearum isolated in Florida. Disease indices: $0=$ no symptoms, $1=$ one leaf with symptoms, $2=$ two or three leaves wilted, $3=$ all except the top two or three leaves wilted, and $4=$ whole plant wilted. Tobacco cultivar: NC55. Least significant difference $(P \leq 0.05)$ for final disease index of the treatments ( 28 days after inoculation) is 0.86 . Error bars indicate standard errors of the means of two repeated experiments. variation among isolates from all over the world (Fig. 2).

HR on tobacco. Tomato isolate Rs5 and hydrangea isolate Rs116 induced a strong and complete HR in tobacco leaves $23 \mathrm{~h}$ after infiltration, with infiltrated areas completely collapsed and desiccated; this GMI1000 from tomato, which was used as a positive control. In contrast, pepper isolate Rs121, tomato isolate $\mathrm{K} 60$, and R3B2 geranium isolate UW551 induced no detectable response at $23 \mathrm{~h}$ post infiltration. Race 1 biovar 1 sequevar 5 geranium isolate Rs37 induced a partial HR that resembled a scattering of small necrotic freckles in the infiltrated area.

\section{DISCUSSION}

Discriminating diagnostically relevant subgroups of $R$. solanacearum poses great challenges because of strain heterogeneity and the large host range of this pathogen. Accurate race-specific detection of the pathogen is essential for crops susceptible to both race 1 and race 3 strains, such as geranium, because any finding of R3B2infected geranium plants in the United States requires a strict government quarantine and eradication responses. Further, any such find of a Select Agent requires high-level security and reporting. Geranium growers have a zero tolerance for $R$. solanacearum, because it is likely that the discovery of any race on geranium will result in costly eradication and sanitation procedures (13). In September 2004, R. solanacearum strains isolated from wilted geraniums and associated irrigation pond tially clonal, with very little sequence response resembled that induced by strain 
water in a commercial ornamental nursery in Quincy, FL, initially were identified inaccurately as R3B2 based on a real-time PCR assay. As a consequence, the 1,500 geranium plants at the facility were destroyed and the facility was sanitized. The facility was kept under a hold order until correct race determination and, ultimately, the thousands of remaining plants in the facility could not be distributed beyond Florida.

Biological and bioinformatic evidence presented in this study indicated that the Florida geranium isolates do not belong to $\mathrm{R} 3 \mathrm{~B} 2$. Unlike R3B2 strains, these isolates caused disease on tobacco. The physiological biovar test determined that the geranium strains Rs125 to Rs130 were biovar 1, not biovar 2. DNA from strains Rs125 to Rs130 was not amplified by the 630/631 race 3 -specific primer set. Finally, none of the $e g l$ sequence fragments analyzed from these isolates was closely related to those in the R3B2 cluster, which belong to sequevars 1 and 2 exclusively (9). Phylogenetic analysis of $e g l$ sequences placed these isolates in sequevar 5, a distinct subcluster of phylotype II biovar 1 strains remote from the R3B2 cluster. Collectively, these results indicate unambiguously that these geranium strains belong to biovar 1. Interestingly, the B2 primers of Weller et al. (48) did weakly amplify a product from strains Rs125 to Rs130 DNA in real-time PCR, with a delayed threshold cycle (Table 1). The B2 assay also weakly amplified the expected product from Colombian biovar 1 isolate UW154 and fully amplified the product from CIP 430, a Peruvian biovar 1 strain that is known to carry the same target sequence as all biovar 2 (phylotype II, sequevars 1 and 2) isolates (8). Furthermore, when the PCR products of the B2 amplification reaction were visualized by gel electrophoresis, an approximately 72-bp product was visible for additional biovar 1 strains which were not detected in the real-time assay, presumably due to the specific homology of the detection probe to the amplified product. Faint bands were visible for strains Rs116 and Rs117 isolated from hydrangea in 2003, and for UW27, UW341, and UW387, which were isolated in Florida in 1955, 1979, and 1984, respectively (data not shown). These data suggest that the B2 primer/probe real-time PCR assay may give false positives under some conditions. Given the high cost of a misdiagnosis, it seems advisable to use at least two independent diagnostic methods to confirm that a suspect isolate is $R$. solanacearum R3B2.

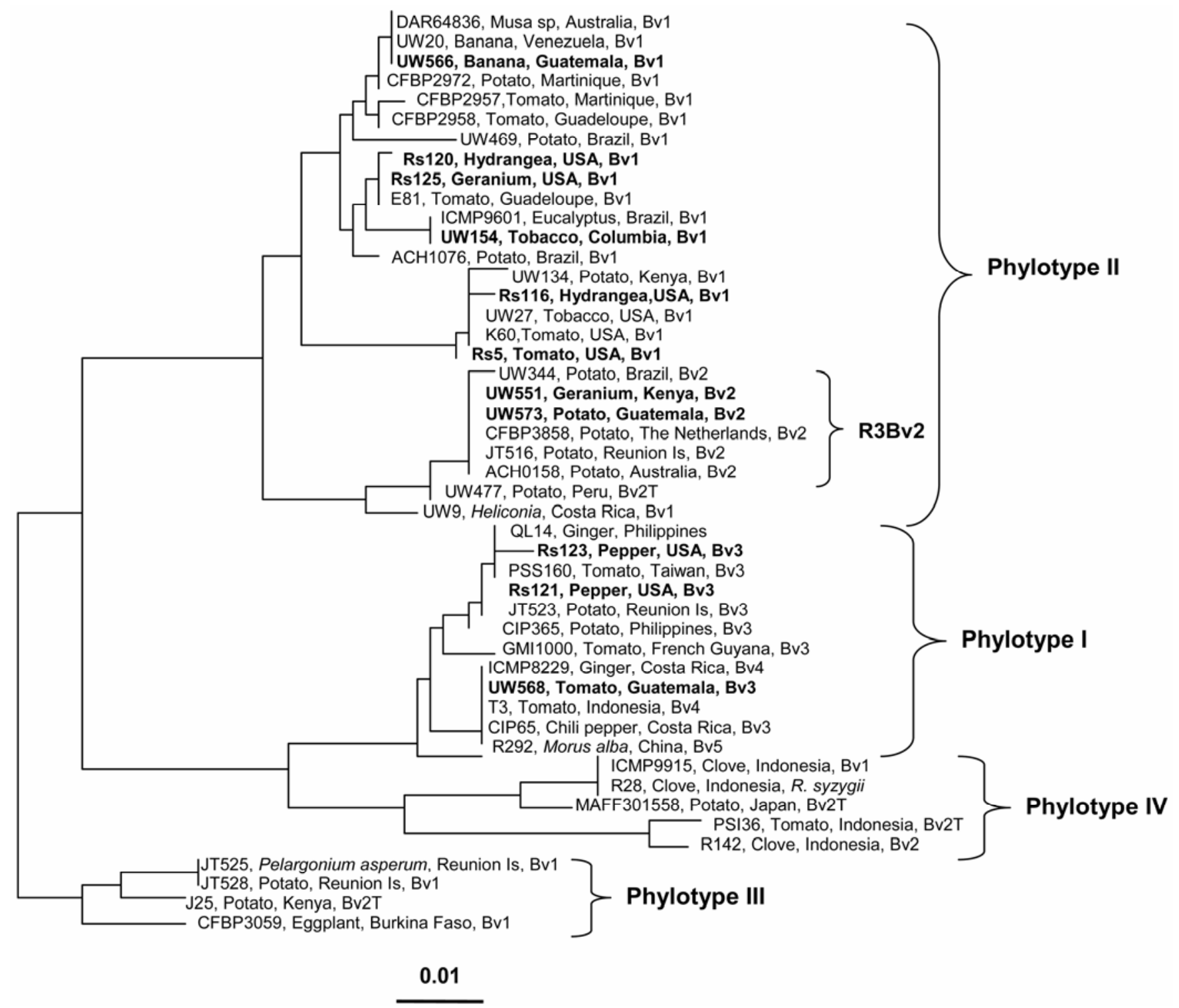

Fig. 2. Phylogenetic tree of the Ralstonia solanacearum species complex, based on a partial (750-bp) sequence of the endoglucanase (egl) gene from diverse $R$. solanacearum strains. Some sequences are reported here and others were published previously $(9,33)$. The figure shows phylogenetic locations for one or two representative strains (shown in bold) from those whose sequence data were determined for this study, because all new Florida strains fell into three distinct clusters of closely related strains. The rooted tree was constructed using the ARB program in Biology Workbench. The $e g l$ sequences reported here have been deposited in the GenBank database. 
It is noteworthy that, whereas R3B2 strains do not cause disease on tobacco, some race 1 biovar 1 (R1B1) strains also share this trait. Florida strain Rs5 did not cause disease on NC55 tobacco in repeated inoculations. Two R1B1 strains, SC12 and Rso 81-5, isolated from tomato in South Caroline and Georgia, respectively, were not pathogenic on K326 tobacco (42). Only 7 of the 40 R1B1 strains isolated from Pothos produced disease symptoms on Hicks tobacco (31). $R$. solanacearum causes serious disease losses in tobacco production in North and South Carolina; however, the disease rarely occurs on tobacco in Georgia and Florida, although $R$. solanacearum is common in these two states $(10,20,22,42)$. Robertson et al. (43) reported that this difference in virulence on tobacco among strains in the southeastern United States correlates with the presence of a functional avrA gene. It has been suggested that the $R$. solanacearum isolates that caused southern wilt of geranium in North Carolina in 1981 (45) must be race 3 because they did not cause disease on tobacco. However, because race 1 strains avirulent on tobacco are common, the 1981 North Carolina geranium isolate cannot be classified conclusively by race.

Unlike R3B2 strains, which do not induce an HR on tobacco, biovar 1 strains may or may not induce an HR on tobacco. The tomato strain Rs5 and hydrangea strain Rs116 induced a strong and rapid HR on tobacco. Strain Rs37, which was isolated from geranium in Florida, caused an intermediate partial necrotic response on tobacco. Strain Rs121, representative of the sequevar 13 pepper isolates, induced no HR on tobacco. These results suggest that some of the tested strains were different from the known indigenous strains in Florida because, in the studies of Velupillai and Stall (47), all Florida isolates caused HR on tobacco, although they did not report whether these isolates caused disease on tobacco. Our result was in agreement with the observation that HR-negative biovar 1 isolates can cause disease on tobacco $(39,43)$ whereas HR-positive biovar 1 strains did not (43). However, some studies on $R$. solanacearum strains originating from outside the United States indicated that HR-positive biovar 1 and biovar 3 strains could induce disease on tobacco $(31,39)$. These studies suggest that great variation exists among biovar 1 strains in pathogenicity and HR reactions on tobacco; hence, these traits are not very useful in strain differentiation.

This is the first report that $R$. solanacearum biovar 3 is present and causes natural plant infection in North America. Completion of Koch's postulates confirmed that the three pepper isolates infected and wilted field-grown pepper plants in Hillsborough County, FL. Their pathogenicity on tobacco, negative PCR analysis using the R3B2-specific primers 630/631, and placement in biovar 3 indicated that these strains did not belong to R3B2. Phylogenetic analysis of egl sequences indicated that they clustered with strains isolated from diverse hosts in Asia belonging to sequevar 13. Thus, these Florida pepper strains fell into phylotype I and biovar 3 . Biovar 3 strains are known to be widely distributed in Asia, Australia, Africa, Europe, South America, Central America, and the Caribbean, where they cause significant losses in tomato, pepper, potato, tobacco, eggplant, and other crops $(6,17,27,28,35,37,39,41)$. There is no previous report of biovar 3 strains in North America. The three biovar 3 strains isolated in Florida were highly aggressive on tomato, tobacco, and all three pepper cultivars tested, and caused death of all plants in all experiments. They were significantly more aggressive on tobacco and pepper than biovar 1 strains isolated in Florida from tomato (Rs5) and hydrangea (Rs116 and Rs117). Biovar type and aggressiveness of $R$. solanacearum strains may be linked. Prior et al. (40) reported that biovar 1 strains were more aggressive than biovar 3 strains on one tomato cultivar, Capitan, but not other cultivars. Studies by Lopes et al. (27) with six tomato cultivars also indicated that biovar 1 strains were more aggressive than biovar 3 strains. However, there are also studies indicating that biovar 3 strains were more aggressive than biovar 1 strains on pepper (26). Although the correlation between biovar type and aggressiveness may vary according to strains and type or cultivars of crops studied, the existence of biovar 3 strains that are highly aggressive on pepper and tobacco should be an alert for pepper and tobacco production in Florida, where $R$. solanacearum currently is not considered a severe problem on these crops.

Phylogenetic analysis of the egl gene sequence provides a finer-scale identification of $R$. solanacearum strains; this approach placed four isolates from hydrangea in Florida into sequevar 5 in phylotype II, whereas two other hydrangea isolates fell into sequevar 7. The hydrangea strains were otherwise identical in biovar characterization and similar in pathogenicity on tomato, hydrangea, and tobacco. R. solanacearum was reported as early as 1930 to cause disease in New York on hydrangea (H. arborescens), which was obtained through a greenhouse firm from the south; however, the cause was unconfirmed $(4,20)$. To our knowledge, this article is the first report confirming $R$. solanacearum inducing natural infection on hydrangea plants in Florida, and the first report indicating that two groups of biovar 1 strains with distinct geographic origins can cause bacterial wilt on hydrangea. Analysis of $e g l$ sequences also placed geranium strains Rs125 to Rs130 and Rs37, which were isolated in the 2004 and 2002 bacterial wilt outbreaks in Florida, into sequevar 5, a cluster containing strains from the French West Indies and Brazil. Our results indicate that these sequevar 5 strains, which are distinct from strains indigenous to Florida and may have been imported from the Caribbean, appear to be widely disseminated in Florida and can infect diverse hosts.

In summary, our studies indicated that the various cases of wilting occurring on geranium, hydrangea, and pepper in Florida in 2003 and 2004 were caused by $R$. solanacearum biovars 1 and 3 , and not by the Select Agent group R3B2. These Florida $R$. solanacearum isolates encompassed a surprising diversity of strains, including a cluster of biovar 3 strains isolated from pepper that belong to phylotype I sequevar 13; phylotype II sequevar 5 strains that caused disease on both geranium and hydrangea; and additional hydrangea isolates belonging to phylotype II sequevar 7, which are indigenous to the southeastern United States. It is uncertain how these were imported to Florida, and from where. It is also unknown to what extent these strains have been disseminated in this region. A year-round monitoring and differentiation of $R$. solanacearum in irrigation water and various crop and weed hosts in Florida is underway. These studies may provide more comprehensive information concerning the distribution and potential impact of these diverse strains on solanaceous and ornamental crop production in Florida and other southern states.

\section{ACKNOWLEDGMENTS}

This research was supported by grants from the United States Department of Agriculture (USDA) T-STAR programs (to M. T. Momol, J. B. Jones, and S. M. Olson, grant no. 2003-34135-14077), by a USDA Agricultural Research Service Floral and Nursery Crops Industry Task Force Initiative Specific Cooperative Agreement, and by the University of Wisconsin-Madison College of Agricultural and Life Sciences (to C. Allen). We thank M. Fegan (University of Queensland, Australia) for help with the sequevar and phylogenetic analysis; D. Jones and L. Levy (USDAAPHIS, Beltsville, MD) for sharing strains; A. Whidden, Florida/IFAS Extension in Hillsborough County, for help in obtaining infected pepper plants; and H. Dankers and L. Ritchie for their technical assistance.

\section{LITERATURE CITED}

1. Alvarez, A. M., Trotter, K. J., Swafford, M. B. Berestecky, J. M., Yu, Q., Ming, R., Hepperly, P. R., and Zee, F. 2005. Characterization and detection of Ralstonia solanacearum strains causing bacterial wilt of ginger in Hawaii. Pages 471-478 in: Bacterial Wilt: The Disease and the Ralstonia solanacearum Species Complex. C. Allen, P. Prior, and A. C. Hayward, eds. American Phytopathological Society, St. Paul, MN.

2. Ausubel, F., Brent, R., Kingston, R., Moore, D., Seidman, J., Smith, J., and Struhl, K. 1998. Current Protocols in Molecular Biology. John Wiley and Sons, New York.

3. Buddenhagen, I., and Kelman, A. 1964. Biological and physiological aspects of bacterial wilt caused by Pseudomonas solanacearum. 
Annu. Rev. Phytopathol. 2:203-229.

4. Chupp, C. 1930. Brown blight in New York. Plant Dis. Rep. 14(14):133.

5. Denny, T. P., and Hayward, A. C. 2001. Ralstonia. Pages 151-174 in: Laboratory Guide for Identification of Plant Pathogenic Bacteria, 3rd ed. N. W. Schaad, J. B. Jones, and W. Chun, eds. American Phytopathological Society, St. Paul, MN.

6. Elphinstone, J. G. 2005. The current bacterial wilt situation: a global overview. Pages 9-28 in: Bacterial Wilt: The Disease and the Ralstonia solanacearum Species Complex. C. Allen, P. Prior, and A. C. Hayward, eds. American Phytopathological Society, St. Paul, MN.

7. Elphinstone, J. G., Stanford, H., and Stead, D. E. 1998. Detection of Ralstonia solanacearum in potato tubers, Solanum dulcamara and associated irrigation water. Pages 133-139 in: Bacterial Wilt Disease: Molecular and Ecological Aspects. P. Prior, C. Allen, and J. G. Elphinstone, eds. Springer-Verlag, Berlin.

8. Fegan, M., Holoway, G., Hayward, A. C., and Timmis, J. 1998. Development of a diagnostic test based on the polymerase chain reaction to identify strains of $R$. solanacearum exhibiting the biovar 2 genotype. Pages 34-43 in: Bacterial Wilt Disease: Molecular and Ecological Aspects. P. Prior, C. Allen, and J. Elphinstone, eds. Springer-Verlag, Berlin.

9. Fegan, M., and Prior, P. 2005. How complex is the Ralstonia solanacearum species complex? Pages 449-461 in: Bacterial Wilt: The Disease and the Ralstonia solanacearum Species Complex. C. Allen, P. Prior, and A. C. Hayward, eds. American Phytopathological Society, St. Paul, MN.

10. Fortnum, B. A., and Kluepfel, D. 2005. Mechanization has contributed to the spread of bacterial wilt on flue-cured tobacco in the southeastern USA. Pages 51-59 in: Bacterial Wilt: The Disease and the Ralstonia solanacearum Species Complex. C. Allen, P. Prior, and A. C. Hayward, eds. American Phytopathological Society, St. Paul, MN.

11. Gabriel, D. W., Allen, C., Schell, M., Denny, T. P., Greenberg, J., Duan, Y. P., Flores-Cruz, Z., Huang, Q., Clifford, J. M., Presting, G., Gonzalez, E. T., Reddy, J., Elphinstone, J., Swanson, J., Yao, Y., Mulholand, V., Liu, L., Farmerie, W., Patnaikuni, M., Balogh, B., Norman, D., Alvarez, A., Castillo, J. A., Jones, J., Saddler, G., Walunas, T., Zhukov, A., and Mikhailova, N. 2006. Identification of open reading frames unique to a Select Agent: Ralstonia solanacearum race 3 biovar 2. Mol. PlantMicrobe Interact. 19:69-79.

12. Gillings, M. R., and Fahy, P. 1994. Genomic fingerprinting: towards a unified view of the Pseudomonas solanacearum species complex. Pages 95-112 in: Bacterial Wilt: the Disease and Its Causative Agent, Pseudomonas solanacearum. A. C. Hayward and G. L. Hartman, eds. CAB International, Wallingford, UK.

13. Harmon, P. F., Harmon, C. L., Norman, D., and Momol, T. 2005. Southern wilt of geranium. University of Florida, IFAS, Coop. Ext. Serv.

14. Hayward, A. C. 1964. Characteristics of Pseudomonas solanacearum. J. Appl. Bacteriol. 27:265-277.

15. Hayward, A. C. 1991. Biology and epidemiology of bacterial wilt caused by Pseudomonas solanacearum. Annu. Rev. Phytopathol. 29:6587.

16. Hendrick, C., and Sequeira, L. 1984. Lipopolysaccharide-defective mutants of the wilt pathogen Pseudomonas solanacearum. Appl. Environ. Microbiol. 48:94-101.

17. Horita, M., and Tsuchiya, K. 2001. Genetic diversity of Japanese strains of Ralstonia solanacearum. Phytopathology 91:399-407.

18. Janse, J. D., Araluppan, F. A. X., Schans, J.,
Wenneker, M., and Westerhuis, W. 1998. Experiences with bacterial brown rot, Ralstonia solanacearum biovar 2 race 3 , in the Netherlands. Pages 146-154 in: Bacterial Wilt Disease: Molecular and Ecological Aspects. P. Prior, C. Allen, and J. Elphinstone, eds. Springer-Verlag, Berlin.

19. Janse, J. D., van den Beld, H. E., Elphinstone, J., Simpkins, S., Tjou-Tam-Sin, N. A. A., and Vaerenbergh, J. V. 2004. Introduction to Europe of Ralstonia solanacearum biovar 2, race 3 in Pelargonium zonale cuttings. J. Plant Pathol. 86:147-155.

20. Kelman, A. 1953. The bacterial wilt caused by Pseudomonas solanacearum. A literature review and bibliography. N. C. Agric. Exp. Stn. Tech. Bull. 99:1-194.

21. Kelman, A. 1954. The relationship of pathogenicity of Pseudomonas solanacearum to colony appearance in a tetrazolium medium. Phytopathology 44:693-695.

22. Kelman, A., and Person, H. 1961. Strains of Pseudomonas solanacearum differing in pathogenicity to tobacco and peanut. Phytopathology 51:158-161.

23. Kim, S. H., and Olson, T. N. 2003. Ralstonia solanacearum race 3 , biovar 2 , the causal agent of brown rot of potato, identified in geraniums in Pennsylvania, Delaware, and Connecticut. Plant Dis. 87:450.

24. Kucharek, T. 1998. Bacterial Wilt of Row Crops in Florida. Circ-1207. University of Florida, IFAS, Coop. Ext. Serv.

25. Lambert, C. D. 2002. Agricultural Bioterrorism Protection Act of 2002: Possession, Use, and Transfer of Biological; Agents and Toxins; Interim and Final Rule. (7 CFR Part 331). Federal Register 67:76908-76938.

26. Lopes, C. A., Carvalho, S. I. C., and Boiteux, L. S. 2005. Search for resistance to bacterial wilt in a Brazilian Capsicum germplasm collection. Pages 247-251 in: Bacterial Wilt: The Disease and the Ralstonia solanacearum Species Complex. C. Allen, P. Prior, and A. C. Hayward, eds. American Phytopathological Society, St. Paul, MN.

27. Lopes, C. A., Quezado-Soares, A. M., and de Melo, P. E. 1994. Differential resistance of tomato cultigens to biovars I and III of Pseudomonas solanacearum. Plant Dis. 78:10911094

28. Martin, C., French, E. R., and Nydegger, U. 1982. Strains of Pseudomonas solanacearum affecting Solanaceae in the Americas. Plant Dis. 66:458-460.

29. Mclaughlin, R. J., and Sequeira, L. 1989. Phenotypic diversity in strains of Pseudomonas solanacearum isolated from a single potato field in north eastern Florida. Plant Dis. 73:960-964.

30. Momol, M. T., Pradhanang, P. M., and Lopes, C. A. 2003. Bacterial wilt. Pages 7-8 in: Compendium of Pepper Diseases. K. L. Pernezny, P. D. Roberts, J. F. Murphy, and N. P. Goldberg, eds. American Phytopathological Society, St. Paul, MN.

31. Norman, D. J., and Yuen, J. M. F. 1998. A distinct pathotype of Ralstonia (Pseudomonas) solanacearum race 1, biovar 1 entering Florida in pothos (Epipremnum aureum) cuttings. Can. J. Plant Pathol. 20:171-175.

32. Opina, N., Tavner, F., Hollway, G., Wang, J.-F., Li, T.-H., Maghirang, R., Fegan, M., Hayward, A. C., Krishnapillai, V., Hong, W. F., Holloway, B. W., and Timmis, J. 1997. A novel method for development of species and strainspecific DNA probes and PCR primers for identifying Burkholderia solanacearum (formerly Pseudomonas solanacearum). Asia Pac. J. Mol. Biol. Biotechnol. 5:19-30.

33. Poussier, S., Prior, P., Luisetti, J., Hayward, A. C., and Fegan, M. 2000. Partial sequencing of the $h r p B$ and endoglucanase genes confirms and expands the known diversity within the
Ralstonia solanacearum species complex. Syst. Appl. Microbiol. 23:479-486.

34. Poussier, S., Trigalet-Demery, D., Vandewalle, P., Goffinet, B., Luisetti, J., and Trigalet, A 2000. Genetic diversity of Ralstonia solanacearum as assessed by PCR-RFLP of the hrp gene region. AFLP and 16S rRNA sequence analysis, and identification of an African subdivision. Microbiology 146:1679-1692.

35. Poussier, S., Vandewalle, P., and Luisetti, J. 1999. Genetic diversity of African and worldwide strains of Ralstonia solanacearum as determined by PCR-restriction fragment length polymorphism analysis of the $h r p$ gene region. Appl. Environ. Microbiol. 65:2184-2194.

36. Pradhanang, P. M., Ji, P., Momol, M. T., Olson, S. M., Mayfield, J. L., and Jones, J. B. 2005 Application of acibenzolar-S-methyl enhances host resistance in tomato against Ralstonia solanacearum. Plant Dis. 89:989-993.

37. Pradhanang, P. M., and Momol, M. T. 2001. Survival of Ralstonia solanacearum in soil under irrigated rice culture and aquatic weeds. J. Phytopathol. 149:707-711.

38. Pradhanang, P. M., Momol, M. T., Dankers, H., and Jones, J. B. 2002. First report of Southern wilt caused by Ralstonia solanacearum in geranium in Florida. Plant Health Prog. June 11:1-2.

39. Prior, P., and Steva, H. 1990. Characteristics of strains of Pseudomonas solanacearum from the French West Indies. Plant Dis. 74:13-17.

40. Prior, P., Steva, H., and Cadet, P. 1990. Aggressiveness of strains of Pseudomonas solanacearum from the French West Indies (Martinique and Guadeloupe) on tomato. Plant Dis. 74:962-965.

41. Raymundo, A. K., Orlina, M. E., Lavina, W. A., and Opina, N. L. 2005. Comparative geome plasticity of tomato and banana strain of Ralstonia solanacearum in the Philippines. Pages 387-393 in: Bacterial Wilt: The Disease and the Ralstonia solanacearum Species Complex. C. Allen, P. Prior, and A. C. Hayward, eds. American Phytopathological Society, St. Paul, MN.

42. Robertson, A. E., Fortnum, B. A., Wood, T. C., and Kluepfel, D. A. 2001. Diversity of Ralstonia solanacearum in the southeastern United States. Beitr. Tabakforsch. Int. 19:323-331.

43. Robertson, A. E., Wechter, W. P., Denny, T. P., Fortnum, B. A., Wood, T. C., and Kluepfel, D. A. 2004. Relationship between avirulence gene (avrA) diversity in Ralstonia solanacearum and bacterial wilt incidence. Mol. PlantMicrobe Interact. 17:1376-1384.

44. Salanoubat, M., Genin, S., Artiguenave, F. Gouzy, J., Mangenot, S., Arlat, M., Billault, A. Brottier, P., Camus, J., Cattolico, L., Chandler, M., Choisne, N., Claudel-Renard, C., Cunnac, S., Demange, N., Gaspin, C., Lavie, M. Moisan, A., Robert, C., Saurin, W., Schiex, T. Siguier, P., Thebault, P., Whalen, M., Wincker, P., Levy, M., Weissenbach, J., and Boucher, C. A. 2002. Genome sequence of the plant pathogen Ralstonia solanacearum. Nature 415:497502.

45. Strider, D. L., Jones, R. K., and Haygood, R. A. 1981. Southern wilt of geranium caused by Pseudomonas solanacearum. Plant Dis. 65:5253.

46. Swanson, J. K., Yao, J., Tans-Kersten, J. K., and Allen, C. 2005. Behavior of Ralstonia solanacearum race 3 biovar 2 during latent and active infection of geranium. Phytopathology 95:136-143

47. Velupillai, M., and Stall, R.E. 1984. Variation among strains of Pseudomonas solanacearum from Florida. Proc. Fla. State Hortic. Soc. 97:209-213

48. Weller, S. A., Elphinstone, J. G., Smith, N. C. Boonham, N., and Stead, D. 2000. Detection of Ralstonia solanacearum strains with a quantitative, multiplex, real-time fluorogenic 
PCR (TaqMan) assay. Appl. Environ. Microbiol. 66:2853-2858.

49. Williamson, L., Hudelson, B. D., and Allen, C. 2002. Ralstonia solanacearum strains isolated from geranium belong to race 3 and are patho- genic on potato. Plant Dis. 86:987-991.

50. Winstead, N. N., and Kelman, A. 1952. Inoculation techniques for evaluating resistance to Pseudomonas solanacearum. Phytopathology 42:628-634.
51. Yu, Q., Alvarez, A. M., Moore, P. H., Zee, F Kim, M. S., de Silva, A, Hepperly, P. R., and Ming, R. 2003. Molecular diversity of Ralstonia solanacearum isolated from ginger in $\mathrm{Ha}-$ waii. Phytopathology 93:1124-1130. 